\title{
Isocrinid crinoids from the late Cenozoic of Jamaica
}

\author{
Stephen K. Donovan \\ Department of Geology, University of the West Indies, Mona, Kingston 7, Jamaica
}

Date Received April 8, 1994

Date Accepted August 26, 1994

\begin{abstract}
Eight species of isocrinines have been documented from the Lower Cretaceous to Pleistocene of Jamaica. New finds include a second specimen of a Miocene species from central north Jamaica, previously regarded as Diplocrinus sp. but reclassified as Teliocrinus? sp. herein. Extant Teliocrinus is limited to the Indian Ocean, although Miocene specimens have been recorded from Japan, indicating a wider distribution during the Neogene. One locality in the early Pleistocene Manchioneal Formation of eastern Jamaica has yielded three species of isocrinine, Cenocrinus asterius (Linné), Diplocrinus maclearanus (Thomson) and Neocrinus decorus Thomson. These occur in association with the bourgueticrinine Democrinus sp. or Monachocrinus sp. These taxa are all extant and suggest a minimum depositional depth for the Manchioneal Formation at this locality of about $180 \mathrm{~m}$. This early Pleistocene fauna represents the most diverse assemblage of fossil crinoids documented from the Antillean region.
\end{abstract}

Huit espèces d'isocrinines de la période du Crétacé inférieur au Pléistocène de la Jamaïque ont été documentées. Les nouvelles découvertes comprennent un deuxième spécimen d'une espèce du Miocène du nord central de la Jamaïque, auparavant considérée comme l'espèce Diplocrinus, mais reclassifiée en tant que Teliocrinus? aux présentes. Le Teliocrinus existant est limité à l'océan Indien, même si on a relevé des spécimens du Miocène au Japon, ce qui est révélateur d'une distribution plus répandue au cours du Néogène. Un emplacement de la formation de Manchioneal du Pléistocène inférieur dans l'est de la Jamaïque a livré trois espèces d'isocrinines : le Cenocrinus asterius (Linné), le Diplocrinus maclearanus (Thomson) et le Neocrinus decorus (Thomson). Ceux-ci sont présents en association avec les bourgueticrinines Democrinus ou Monachocrinus. Ces taxons sont tous existants et ils permettent de supposer que la formation de Manchioneal aurait une profondeur minimale de sédimentation d'environ $180 \mathrm{~m}$ à cet endroit. Cette faune du Pléistocène inférieur représente l'assemblage le plus diversifié de crinoïdes fossiles documentés dans la région des Antilles.

[Traduit par la rédaction]

\section{INTRODUCTION}

Few fossil crinoids are known from Jamaica; nevertheless, they are probably the best known fauna of this group from the Antillean islands. Most of the described taxa are based on just one or a few specimens. Of the eight species hitherto recognized (Table 1), five are isocrinines; all of these are recorded from a single columnal or pluricolumnal only and each from a different locality and horizon. It is therefore considered significant to report further specimens from two of these horizons, generally showing superior preservation to those originally described. The discovery of a moderately rich crinoid locality in the early Pleistocene of eastern Jamaica, including three species of isocrinine and a bourgueticrinine, represents the first site on the island to yield more than one species of crinoid and has produced more specimens than all of the other Cenozoic sites combined.

Terminology of the crinoid stem used herein follows Moore et al. (1968), Roux (1977), Ubaghs (1978) and Webster (1974). The classification of articulate crinoids follows Simms (1988). The protocol of open nomenclature follows Bengtson (1988). The specimens described herein are deposited in the Natural History Museum, London (BMNH) and the Florida Museum of Natural History (UF).

\section{Systematic Paleontology}

\author{
Class Crinoidea J.S. Miller, 1821 \\ Subclass Articulata von Zittel, 1879 \\ Order Isocrinida Sieverts-Doreck, 1952 \\ Suborder Isocrinina Gislén, 1924 \\ Family Isocrinidae Gislén, 1924
}

\section{Genus Neocrinus Thomson, 1864 \\ Neocrinus decorus Thomson, 1864 \\ Figure 2.1, 2.2, 2.4, 2.6, 2.7, 2.9-2.11}

Material: Twelve columnals and pluricolumnals, BMNH EE 5052, EE 5053, EE 5057[2], EE 5060, EE 5062 (Fig. 2.7, 2.10, 2.11), EE 5064 (Fig. 2.1, 2.4), EE 5065[2] (Fig. 2.2, 2.6), EE 5065[3] (Fig. 2.9), EE 5067-EE 5070.

Occurrence: Cliffs and associated fallen blocks exposed near the mouth of the Christmas River, parish of Portland, eastern Jamaica (Fig. 1.1; GR 798 421, old 1:50,000 series, sheet M, 'Port Antonio'). Upper Coastal Group, Manchioneal Formation. Early Pleistocene. 
Table 1. Fossil crinoids of Jamaica (after Donovan, 1989; Donovan et al., 1993, 1994; Dixon et al., 1994). * = discussed herein.

\begin{tabular}{|c|c|}
\hline \multicolumn{2}{|l|}{ Order ISOCRINIDA } \\
\hline \multicolumn{2}{|l|}{ Suborder COMATULIDINA } \\
\hline \multicolumn{2}{|l|}{ Incertae familiae } \\
\hline Brachial or pinnular ossicle & late Oligocene \\
\hline Brachial ossicles indet. & late Cretaceous \\
\hline \multicolumn{2}{|l|}{ Suborder ISOCRININA } \\
\hline \multicolumn{2}{|l|}{ Family ISOCRINIDAE } \\
\hline * Neocrinus decorus Thomson & early Pleistocene \\
\hline \multicolumn{2}{|l|}{ Family CAINOCRINIDAE } \\
\hline * Teliocrinus? sp. & early Miocene \\
\hline \multicolumn{2}{|l|}{ Family ISSELICRINIDAE } \\
\hline Austinocrinus sp. & early Aptian \\
\hline cf. Cenocrinus asterius (Linné) & early Pleistocene \\
\hline * Cenocrinus asterius (Linné) & early Pleistocene \\
\hline * Diplocrinus maclearanus (Thomson) & early Pleistocene \\
\hline Isselicrinus cubensis? (Valette) & early Eocene \\
\hline \multicolumn{2}{|l|}{ Incertae familiae } \\
\hline Isocrinid sp. indet. & middle Eocene \\
\hline \multicolumn{2}{|l|}{ Suborder BOURGUETICRININA } \\
\hline \multicolumn{2}{|l|}{ Family BATHYCRINIDAE } \\
\hline * Democrinus sp. or Monachocrinus sp. & early Pleistocene \\
\hline \multicolumn{2}{|l|}{ Order ROVEACRINIDA } \\
\hline \multicolumn{2}{|l|}{ Family SACCOCOMIDAE } \\
\hline Applinocrinus cretacea (Bather) & Maastrichtian \\
\hline
\end{tabular}

Description: For a description of the stem of extant $N$. decorus, see Donovan (1984).

Remarks: The Pleistocene columnals illustrated herein compare closely with those of extant $N$. decorus (for example, compare Fig. 2.1, 2.4 herein with Roux, 1977, figs. 7C, 19; Donovan, 1984, pl. 74, fig. 2). Even though the trabeculae are encrusted by microspar, the rectilinear stereom of the areola petals is identical to that of living examples (compare Fig. 2.6 with Roux, 1977, fig. 5A; Donovan, 1984, pl. 75, fig. 7). The symplectial facet of $N$. decorus is easily discerned from those of Diplocrinus maclearanus and Cenocrinus decorus (see below) by its distinctive, teardrop-shaped areola petals. Extant $N$. decorus occurs in the tropical western Atlantic, including off Jamaica (Meyer et al., 1978, p. 425).

The cliffs in the Manchioneal Formation near the mouth of the Christmas River are only the second moderately rich, crinoid-bearing succession to be identified from the Jamaican rock record, the fauna consisting of Cenocrinus asterius (Linné), Diplocrinus maclearanus (Thomson), Neocrinus decorus and Democrinus sp. or Monachocrinus sp. (see below). The first such locality, at San San Bay, parish of Portland (Robinson, 1969), is in the same unit, but is unfortunately now concealed by a retaining wall (Donovan, 1989). Columnals were quite common at San San Bay (Robinson, 1969, 1971), but the taxonomic diversity of this locality is unknown. The present author and co-workers have examined the Manchioneal Formation for brachiopods at a number of localities, but have not previously noted associated crinoids. The contact with the underlying Bowden
Formation (Pliocene) is apparent at Christmas River, indicating that the crinoid-rich beds are low in the Manchioneal Formation. Many of the specimens from Christmas River have been collected from fallen blocks.

Evidence that pluricolumnals may have lain on the seafloor for some time between death and final burial is given by an epifaunal, serpulid worm tube (Fig. 2.11). This encrusts two adjacent columnals, which presumably would have been impracticable when the crinoid was alive due to the flexibility of the column (compare with Donovan, 1993, fig. 2C). Although massive encrusting epibionts are not uncommon on Paleozoic crinoids (Meyer and Ausich, 1983), presumably immobilzing the column in the region of attachment, the Pleistocene specimen is small and fragile. It thus suggests that the column was not capable of flexure (=dead) when encrusted.

\section{Family Cainocrinidae Simms, 1988}

\section{Genus Teliocrinus Döderlein, 1912 \\ Teliocrinus? sp. \\ Figure 3 \\ 1993 Diplocrinus sp., Donovan et al., pp. 126-127, fig. 4.}

Material: Two internodal columnals, UF 67000 (Fig. 3) and UF 38939 (Donovan et al., 1993, fig. 4).

Occurrence: Disused quarry about $5 \mathrm{~km}$ west of Duncans police station, on the southern side of the main $\mathrm{Al}$ (north coast) road, parish of Trelawny, central north Jamaica (Fig. 1.2; ap- 

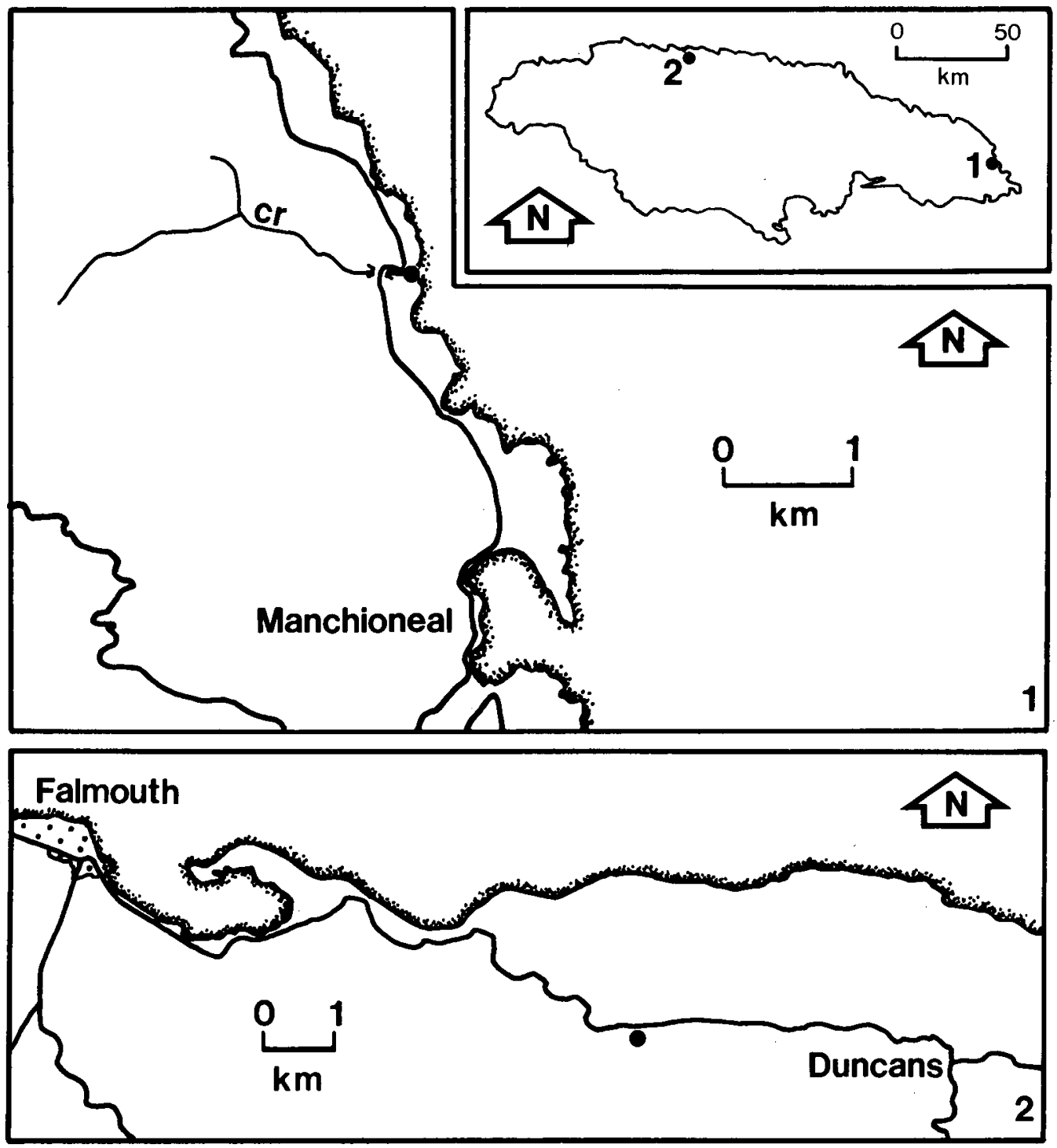

Fig. 1. Locality maps. The inset map of Jamaica shows the positions of main maps (1) and (2). (1) Christmas River area, eastern Jamaica (rivers other than the Christmas River are not shown for simplicity). (2) Duncans-Falmouth area, central north Jamaica. Key: filled circles = crinoid localities, stippled line $=$ coast, thick lines $=$ main roads, thin line marked $\mathrm{cr}=$ Christmas River.

proximate GR 349 570, old 1:50,000 series, sheet C, 'Montego Bay-Falmouth'). Sign Member(?), Montpelier Formation, White Limestone Group. Miocene, probably early Miocene (E. Robinson, personal communication).

Description: (Revised after Donovan et al., 1993). Columnal outline weakly pentastellate with strongly rounded angles. Axial canal small, central and circular in outline. Articulation symplectial, arranged about five slender, elongate, lensoid areola petals that correspond to the columnal angles. Areola petals separate, except adjacent to lumen, and open. Crenulae perpendicular to subperpendicular to circumference of areola petals. Crenulae short, unbranched, 6 to 7 culmina along each side of the areola petals, with crenulae of adjacent petals separate. Triangular naked zones occur adjacent to the circumference in interpetaloid zones. Latus gently convex and unsculptured.

Dimensions: UF 67000 - columnal height $(\mathrm{KH})=c a .1 .5 \mathrm{~mm}$, columnal diameter $(\mathrm{KD})=6 \mathrm{~mm}$, facet diameter $=5.8 \mathrm{~mm}$, lumen diameter $=0.35 \mathrm{~mm}$; UF $38939-\mathrm{KH}=1.6 \mathrm{~mm}, \mathrm{KD}=$ $5.7 \mathrm{~mm}$.

Remarks: This Miocene species was originally described on the basis of UF 38939 (Donovan et al., 1993), a broken internodal. UF 67000 is better preserved (Fig. 3), being unbroken, with the lumen exposed and at least some petals reasonably clean (Fig. 3.3). The areola petals are now recognized to be open, not closed as was originally reported; the crenulae of adjacent petals are apparently separate (Fig. 3.1, 3.3) (Donovan et al., 1993).

The Miocene columnals compare reasonably well with those of extant species of Diplocrinus, such as D. maclearanus, $D$. alternicirrus and D. wyvillethomsoni (Roux, 1977; Macurda and Roux, 1981), conspicuous similarities include the slender, elongate, open petals. The triangular naked zone at the circumference in the interpetaloid zones are similar to those in $D$. alternicirrus (Roux, 1977, figs. 7F, 16) and D. maclearanus (Macurda and Roux, 1981, pl. 15.4-15.7). However, all three 


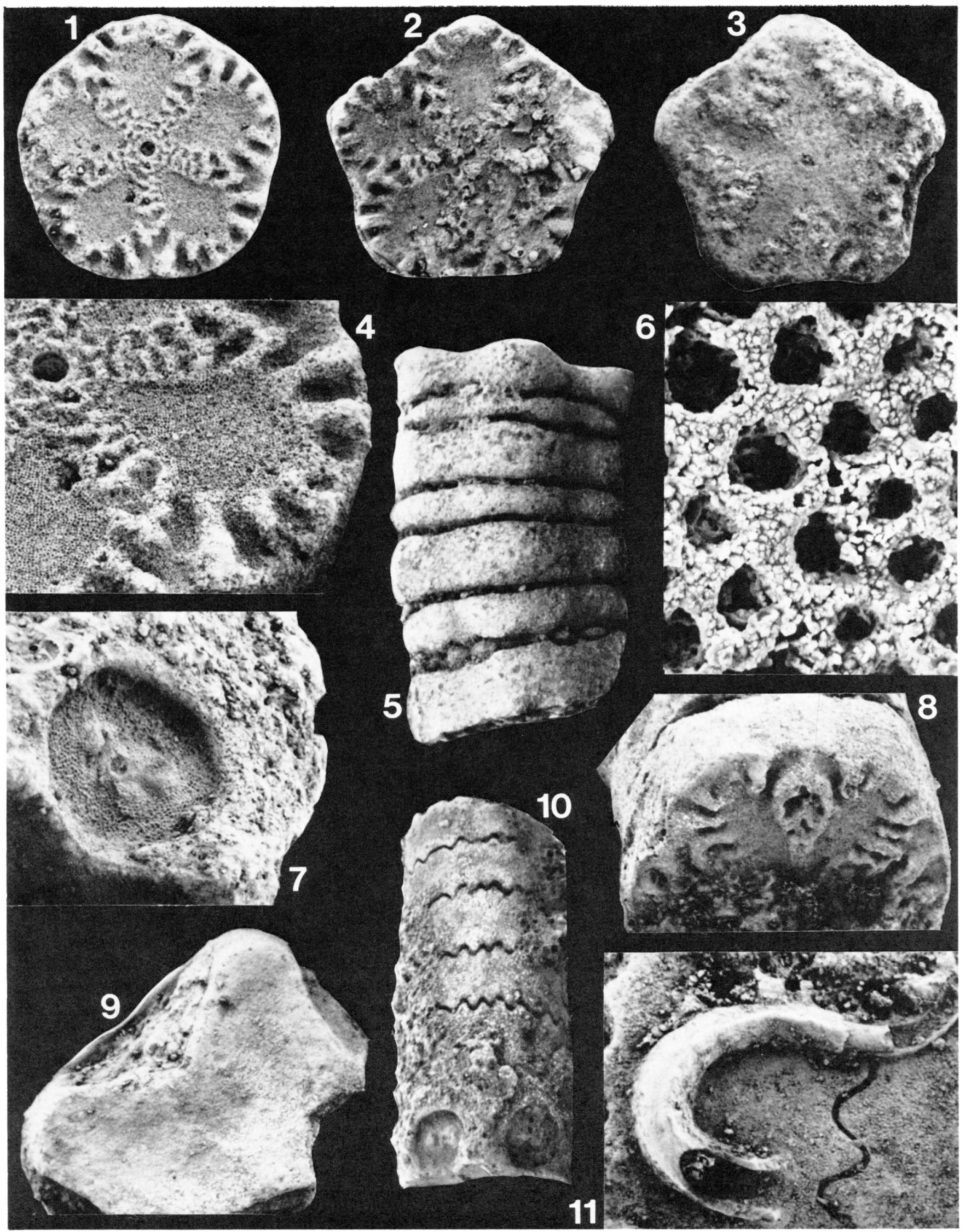




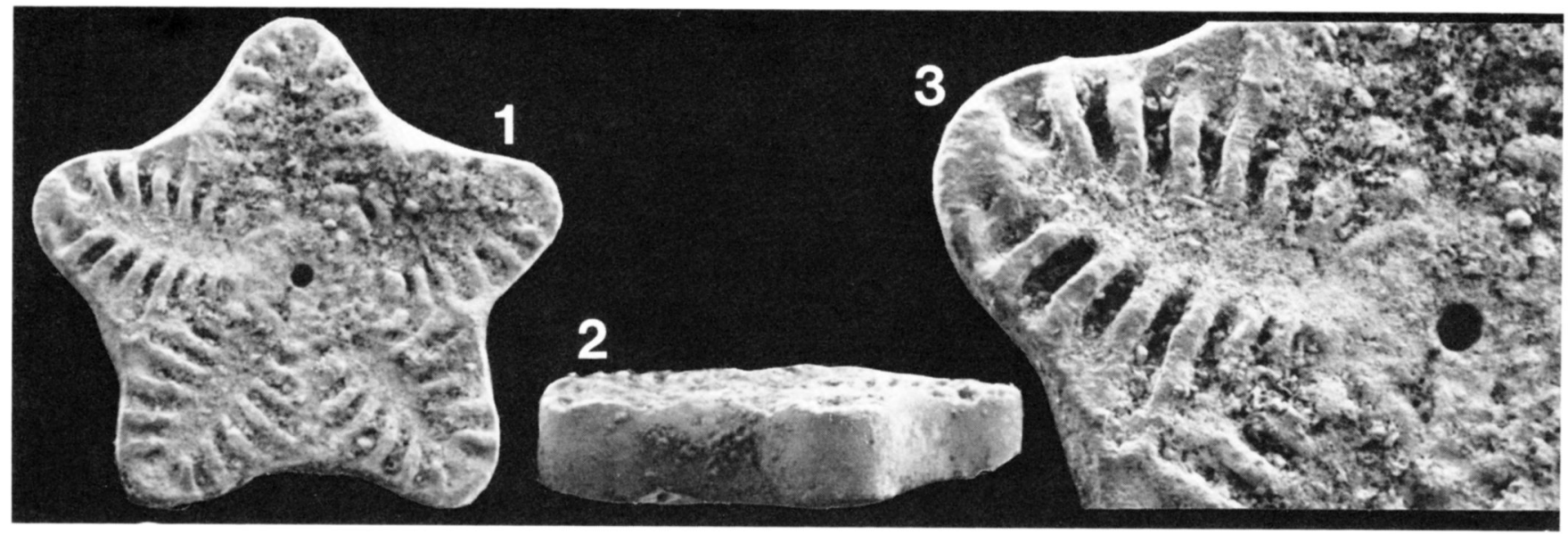

Fig. 3. Teliocrinus? sp. from the Miocene of Jamaica, UF 67000. (1) Articular facet, x9. (2) Lateral view, x9. (3) Detail of an areola petal, x18. Scanning electron micrographs of specimens coated with $60 \%$ gold-palladium.

Recent species differ from the fossil in that the culmina are relatively narrower (and are thus more plentiful) in the latter, whereas culmina of adjacent petals remain separate, that is, there is an interpetaloid groove. The three extant species mentioned above have only 4 to 5 culmina along each side of the areola petals, but the Miocene species has 6 to 7 (Fig. 3.1, 3.3; Donovan et al., 1993, fig. 4). As discussed above, the distinguishing features of Diplocrinus include the lanceolate areola shape, the open crenularium with less than 8 crenulae in each petaloid zone, and an undifferentiated interpetaloid zone without an interpetaloid groove (Roux, 1977, table 2). The presence of more than 10 culmina per petal and interpetaloid grooves in the Jamaican specimen suggests that this taxon is closer to Teliocrinus Döderlein, a genus otherwise only known from the Recent of the Indian Ocean (Roux, 1977, table 1; Rasmussen, 1978, p. T860) and the Miocene of Japan (Oji, 1990). Comparison with the symplectial articulations of the type species, $T$. springeri A.H. Clark, 1909, shows them to be similar (Roux, 1977, figs. $7 \mathrm{E}, 15)$. This perhaps suggests that the Jamaican fossil specimens represent a new species of Teliocrinus, although this generic identification is not yet certain. It is desirable that more is known of the skeleton of the Jamaican species before it is formally named. Dr. T.K. Baumiller (written communication) has also noted a similarity between the Jamaican species and Isocrinus sp. from the Miocene of Japan (Oji, 1990, fig. 6.7, 6.8).

Oji (1990) noted that extant Teliocrinus is limited to the tropical Indian Ocean, but it did extend into the western Pacific during the Miocene. If the present identification is correct, in the Miocene its range also extended into the Caribbean. This was facilitated by the absence of the Central American land bridge, which started to interrupt deep water circulation from the Pacific during the Miocene and became an exposed land mass in the Plio-Pleistocene (Pindell and Barrett, 1990, p. 419).

\section{Family Isselicrinidac Klikushin, 1977}

\section{Genus Cenocrinus Thomson, 1864 \\ Cenocrinus asterius (Linné, 1767) \\ Figure 4}

Material: An internodal, BMNH EE 5050 (Fig. 4). Two pluricolumnals, BMNH EE 5051, EE 5055, are also tentatively included in this species.

Occurrence: Cliffs and associated fallen blocks exposed near the mouth of the Christmas River, parish of Portland, eastern Jamaica (Fig. 1.1; GR 798 421, old 1:50,000 series, sheet M, 'Port Antonio'). Manchioneal Formation, Upper Coastal Group. Early Pleistocene.

Description: Pentalobate internodal columnal with strongly rounded angles. Lumen central, small and circular. Articulation symplectial, arranged about five moderately broad, lensoid areola petals that correspond to the columnal angles. Petals separate, divided centrally by a prominent perilumen. Crenulae mainly perpendicular to circumference of areola petals. Crenulae short, unbranched, 6 to 7 culmina along each side of areola petals, with crenulae of adjacent petals coalescing towards the center. Triangular naked zones occur adjacent to the circumference in interpetaloid zones. Columnal low. Latus slightly convex and unsculptured.

Fig. 2. Early Pleistocene crinoid columnals and pluricolumnals from Jamaica. (1, 2, 4, 6, 7, 9-11) Neocrinus decorus Thomson, 1864. (1, 4) BMNH EE 5064. (1) Articular facet, x14. (4) Detail of an areola petal, x34. (2, 6) BMNH EE 5065[2]. (2) Articular facet, x14. (6) Stereom trabelculae of areola petal overgrown by microspar, $x 850 .(7,10,11) \mathrm{BMNH}$ EE 5062. (7) Cirral facet of nodal, x32. (10) Pluricolumnal, x7.5. (11) Serpulid worm tube encrusting pluricolumnal, $\times 39$. (9) BMNH EE 5065[3], distal cryptosymplectial articulation of a broken nodal columnal, $\times 14$. (3, 5, 8) Diplocrimus maclearanus (Thomson). (3) BMNH EE 5057[1], articular facet, x12. (5) BMNH EE 5058, pluricolumnal (internoditaxis), with cryptosymplectial articulation at top, $x 8$. (8) BMNH EE 5059, apparent growth deformation of facet, $x 14$. Scanning electron micrographs of specimens coated with $60 \%$ gold-palladium. 

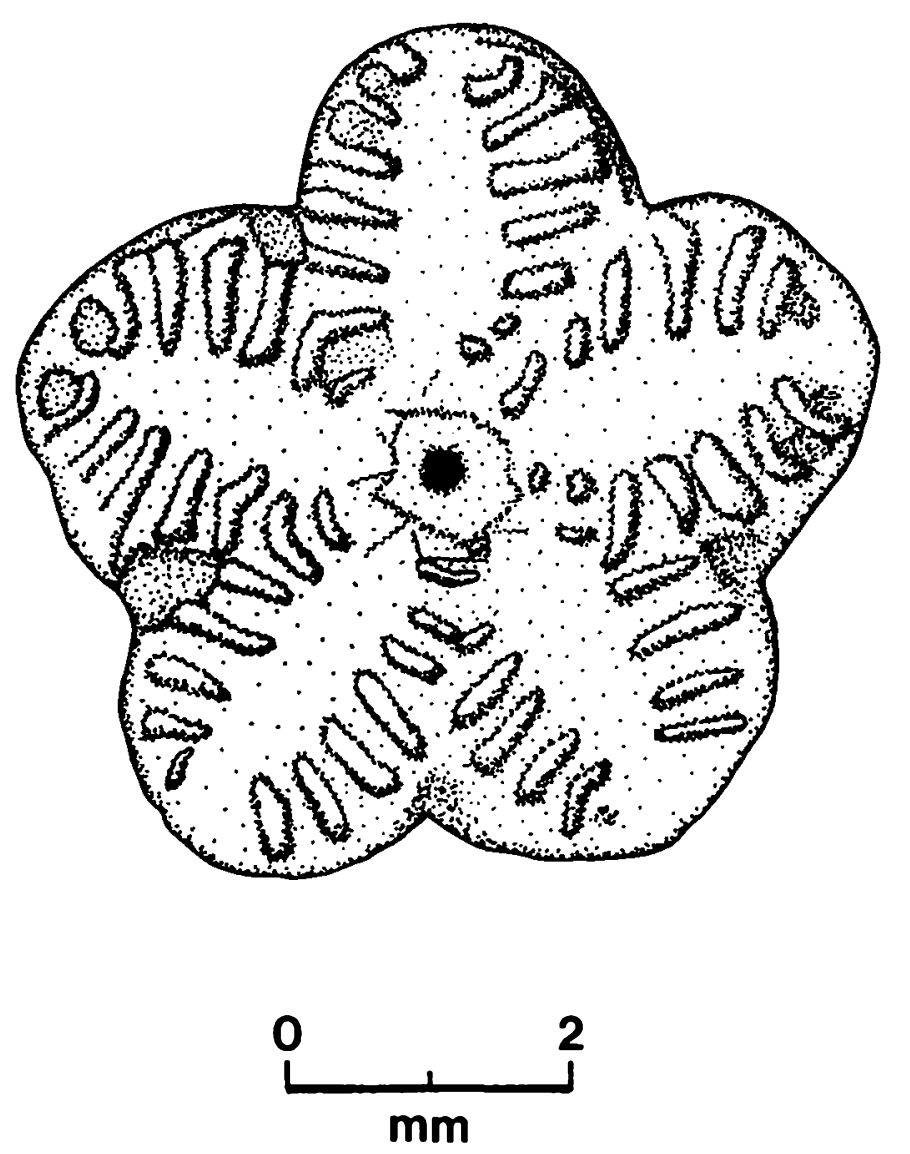

Fig. 4. Cenocrinus asterius (Linné, 1767) from the early Pleistocene of Jamaica, articular facet, BMNH EE 5050. Camera lucida drawing.

Remarks: Donovan (1989) identified cf. Cenocrinus asterius from the Manchioneal Formation at San San Bay (Table 1), based on a single, poorly preserved columnal. Comparison of BMNH EE 5050 with illustrations of the articular facet in extant C. asterius (Roux, 1977, fig. 3E, F, 13; Donovan, 1989, fig. 2C, D, F; Donovan et al., 1993, fig. 3.7) suggests that it is conspecific, although the specimens illustrated by Roux appear to have slightly more angular areola petals.

Extant $C$. asterius is known to occur at water depths of 183 to $585 \mathrm{~m}$ in the western Atlantic, including offshore Jamaica (Meyer et al., 1978, p. 424). This suggests a minimum depth of deposition for the Manchioneal Formation at Christmas River of about $180 \mathrm{~m}$; the other two nominal species from this locality are known from minimum depths of 154 ( $N$. decorus) and $187 \mathrm{~m}$ (D. maclearanus) (Meyer et al., 1978, pp. 425, 426). Even if these depth minima are inaccurate, extant stalked crinoids rarely extend into water depths of less than $150 \mathrm{~m}$ (Lane and Webster, 1980, p. 145). This depth range is in agreement with estimates based on sedimentology and brachiopods (E.N. Doyle, personal communication), echinoids (Donovan and Embden, in press) and 'deep-water alcyonarian corals' (Robinson, 1969 , p. 9). However, it is at variance with data from ostracodes (van den Bold, 1971), which suggest that most deposition of the Manchioneal Formation occurred at less than $100 \mathrm{~m}$ water depth. Crinoids have only been found at San San Bay and Christ- mas River, both basal sections of the Manchioneal Formation, suggesting that this unit is a shallowing-upwards sequence (Donovan and Embden, in press).

\section{Genus Diplocrinus Döderlein, 1912 Diplocrinus maclearanus (Thomson, 1877) Figure 2.3, 2.5, 2.8}

Material: Five columnals and pluricolumnals, BMNH EE 5057[1] (Fig. 2.3), EE 5058 (Fig. 2.5), EE 5059 (Fig. 2.8), EE 5065[1], EE 5066. A further specimen, BMNH EE 5054, is only tentatively included in this species.

Occurrence: Cliffs and associated fallen blocks exposed near the mouth of the Christmas River, parish of Portland, eastern Jamaica (Fig. 1.1; GR 798 421, old 1:50,000 series, sheet M, 'Port Antonio'). Manchioneal Formation, Upper Coastal Group. Early Pleistocene.

Description: For a description of the stem of extant $D$. maclearanus, see Macurda and Roux (1981).

Remarks: Roux (1977, table 2) considered the distinguishing features of Diplocrinus, based on D. alternicirrus (Carpenter) and $D$. wyvillethomsoni (Jeffreys), to be the lanceolate shape of the areola petals, the open crenularium with less than 8 crenulae in each petaloid zone, and an undifferentiated interpetaloid zone without an interpetaloid groove. These features are all apparent in the figured articular facet (Fig. 2.3), which agrees well with that of D. maclearanus (Macurda and Roux, 1981, pl. 15, figs. 4-7). Meyer et al. (1978, p. 426) did not note the occurrence of this species in Jamaican waters at the present day, but it is broadly distributed in the tropical western Atlantic.

BMNH EE 5059 is a pluricolumnal with one exposed facet that compares with $D$. maclearanus. However, the other facet (Fig. 2.8) appears to have a deformity in which two petals are growing particularly close together so that their crenulae are in close association.

\section{Incertae familiae}

Isocrinids gen et sp. indet.

Material: Six pluricolumnals, BMNH EE 5056, EE 5061, EE 5071-EE 5074.

Occurrence: Cliffs and associated fallen blocks exposed near the mouth of the Christmas River, parish of Portland, eastern Jamaica (Fig. 1.1; GR 798 421, old 1:50,000 series, sheet M, 'Port Antonio'). Upper Coastal Group, Manchioneal Formation. Early Pleistocene.

Remarks: The articular facets on these specimens are poorly preserved, but they probably belong to one of the three species documented from Christmas River (see above). 


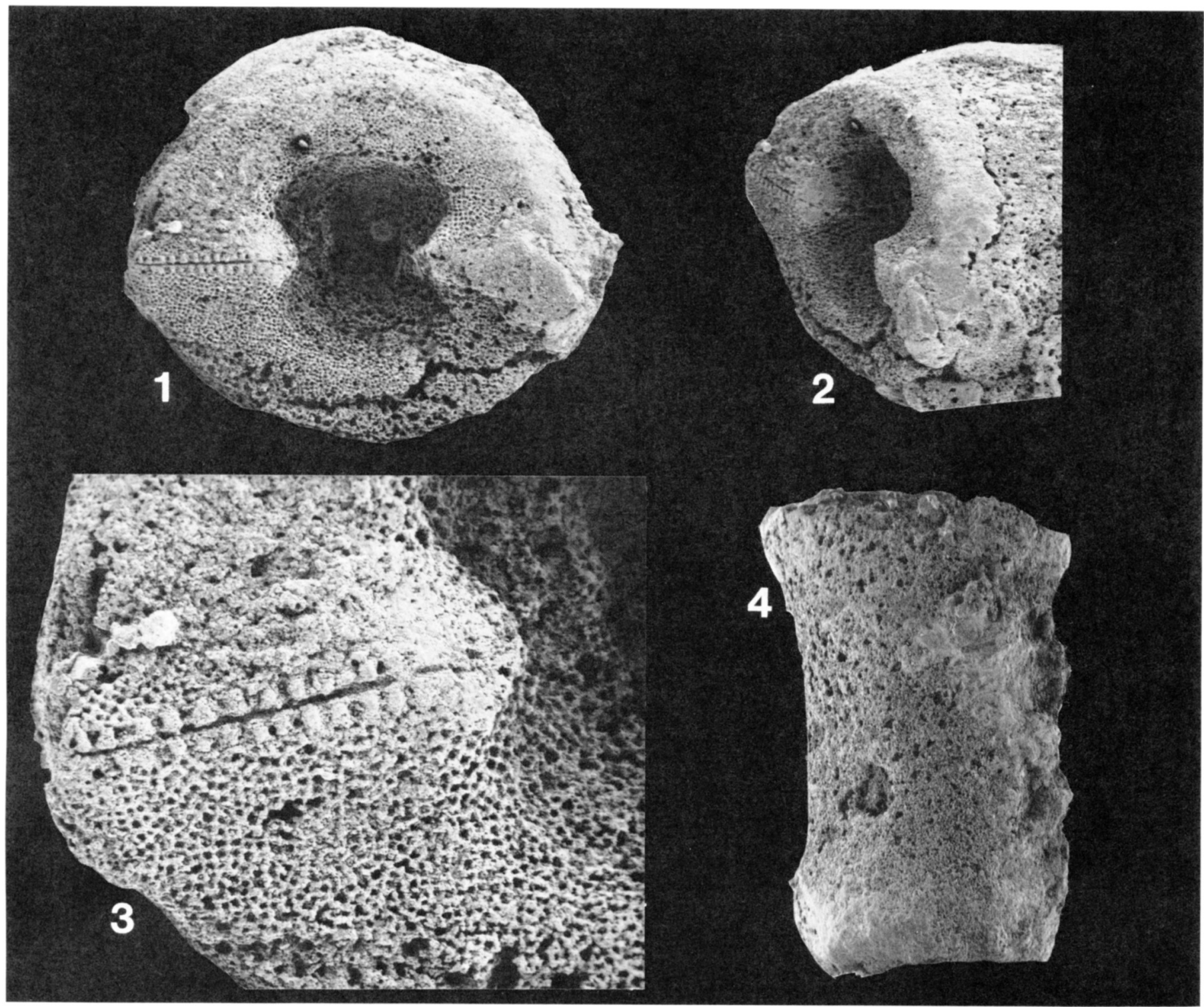

Fig. 5. Democrinus sp. or Monachocrinus sp. from the early Pleistocene of eastern Jamaica. (1-3) BMNH EE 5136. (1) Articular facet, $x 40$. (2) Oblique view of articular facet and latus, $\times 36$. (3) Detail of the fulcral ridge, $\times 125$. (4) BMNH EE 5137, lateral view, $\times 21$. All scanning electron micrographs of specimens coated with $60 \%$ gold-palladium.

\section{Suborder Bourgueticrinina Sieverts-Doreck, 1953 Family Bathycrinidac Bather, 1899}

\section{Democrinus sp. or Monachocrinus sp. \\ Figure 5}

Matcrial: Two columnals, BMNH EE 5136, EE 5137. EE 5136 exposes a well-preserved articular facet (Fig. 5.1, 5.3), although the latus is largely obscured (Fig. 5.2). EE 5137 has poorly preserved articula, but a well-exposed latus (Fig. 5.4).

Occurrence: From fallen blocks exposed near the mouth of the Christmas River, parish of Portland, eastern Jamaica (Fig. 1.1; GR 798 421, old 1:50,000 topographic series, sheet M, 'Port Antonio'). Manchioneal Formation, Upper Coastal Group. Early Pleistocene.
Description: Articular facet lenticular in outline, bifascial, with synarthrial ridge corresponding to long axis. Synarthrial ridge with axial groove flanked by offset knobs separated by large pores. Facet flanking synarthry relatively depressed. Center of columnal strongly depressed, shaped like broad figure ' 8 ', with rounded(?) axial canal at base of depression. Stereom of facet galleried(?), knobs of synarthrial ridge imperforate.

Columnal higher than wide, with unsculptured, planar latera that are slightly convex adjacent to latera. Long axes of latera offset within any columnal.

Remarks: These columnals are typical of bathycrinids, both in their facet and latus geometry (for example, compare with illustrations in Macurda and Meyer, 1975, pl. 2, figs. 4-7; 1976, pl. 1). Their occurrence in the early Pleistocene of the Caribbean is not unexpected, as the only extant bourgueticrinines in 
the region belong to this family (Meyer et al., 1978, pp. 426-427). Unfortunately, without the evidence of the crown, it is impossible to classify these columnals with confidence below familial level. However, the extant Caribbean taxa belong to just two genera, Democrinus Perrier and Monachocrinus A.H. Clark, and it seems probable that these fossil columnals belong to one of these taxa. The Caribbean bathycrinids have the following depth ranges (Meyer et al., 1978): Democrinus rawsonii (Pourtalès), 66 to $652 \mathrm{~m}$; D. conifer (A.H. Clark), 170 to 1750 $\mathrm{m} ; D$. brevis (A.H. Clark), 210 to $878 \mathrm{~m}$; and Monachocrinus caribbeus (A.H. Clark), possibly 421 to $1857 \mathrm{~m}$. On the basis of these figures, it is tentatively suggested that the Manchioneal Formation specimen is most likely to represent a Democrinus sp.

The column of bathycrinids tends to be divided into a short proxistele, with low columnals articulating synostosially, a long mesistele with relatively few, tall columnals, and a short dististele adapted as a radicular attachment structure (Donovan and Pawson, research in progress). The mesistele may be further subdivided into more proximal, cylindrical columnals and more distal columnals with strongly elliptical articular facets, which give the columnal a 'bone-like' appearance. The present specimens obviously belong to the more distal mesistele.

\section{ACKNOWLedGements}

I thank Roger W. Portell (Florida Museum of Natural History) for collecting and loaning the second isocrinid columnal from the Montpelier Formation. Cornelis J. Veltkamp (University of Liverpool) kindly took the SE micrographs in Figures 2 and 3. Figure 5 was photographed in the EM Laboratory, National Museum of Natural History, Smithsonian Institution (USNM), and I thank Walter R. Brown and Susann G. Braden for their assistance. This research was initiated during a period of study leave at the Department of Earth Sciences, University of Liverpool, supported by a Study and Travel Grant from the University of the West Indies and an award from the Leverhulme Trust, and was completed during the tenure of a Senior Research Fellowship at the USNM, all of which are gratefully acknowledged. I thank William I. Ausich (The Ohio State University), Tomasz K. Baumiller (Harvard University), David L. Meyer (University of Cincinnati) and Michael J. Simms (Cheltenham and Gloucester College of Higher Education, U.K.) for their constructive comments on earlier versions of this paper.

Bather, F.A. 1899. A phylogenetic classification of the Pelmatozoa. Report of the British Association for the Advancement of Science for 1898, pp. 916-923.

Bengston, P. 1988. Open nomenclature. Palaeontology, 31, pp. 223-227.

Bold, W.A., VAN DEN. 1971. Ostracoda of the Coastal Group of formations of Jamaica. In Transactions of the 21st Annual Meeting of the Gulf Coast Association of Geological Societies. Edited by W.W. Tyrrell, Jr. and H.W. Anisgard. GCAGS, New Orleans, pp. 325-348.

CLARK, A.H. 1909. Descriptions of seventeen new species of Recent crinoids. Proceedings of the U.S. National Museum, 36, pp. 633-651.

Dixon, H.L., Donovan, S.K., and Veltkamp, C.J. 1994. Crinoid and ophiuroid ossicles from the Oligocene of Jamaica. Caribbean Journal of Science, 30, pp. 143-145.

Dóderlein, L. 1912. Die gestielten Crinoiden der deutschen Tiefsee-Expedition. Wissenschaftliche Ergebnisse Deutsche Tiefsee-Expedition 1898-1899, 17, pp. 1-34. Gustav Fischer, Jena.

Donovan, S.K. 1984. Stem morphology of the Recent crinoid Chladocrinus (Neocrinus) decorus. Palaeontology, 27, pp. 825841.

1989. An isocrinid (Echinodermata: Crinoidea) from the Lower Pleistocene of Portland, eastern Jamaica. Journal of the Geological Society of Jamaica, 25 (for 1988), pp. 3-7.

1993. Contractile tissues in the cirri of ancient crinoids: criteria for recognition. Lethaia, 26, pp. 163-169.

Donovan, S.K. and EMBden, B.J. In press. Early Pleistocene echinoids of the Manchioneal Formation, Jamaica. Journal of Paleontology.

Donovan, S.K., Gordon, C.M., Veltkamp, C.J., and Scotr, A.D. 1993. Crinoids, asteroids and ophiuroids in the Jamaican fossil record. In Biostratigraphy of Jamaica. Edited by R.M. Wright and E. Robinson. Geological Society of America Memoir, 182, pp. 125-130.

Donovan, S.K., Miller, S.A., Graham, A.P., and Dixon, H.L. 1994. New fossil crinoids from Jamaica. Journal of Paleontology, 68, pp. 842-845.

GısLÉN, T. 1924. Echinoderm studies. Zoologiska Bidrag från Uppsala, $9,316 \mathrm{p}$.

KLIKUSHIN, V.G. 1977. Morskiye lilii roda Isselicrinus. Paleontologicheskiy Zhurnal 11, pp. 87-95. In Russian; English translation 1978. Sea lilies of the genus Isselicrinus. Paleontological Journal 11, pp. 87-95.]

LANe, N.G. and Webster, G.D. 1980. Crinoidea. In Echinoderms: Notes for a Short Course. Edited by T.W. Broadhead and J.A. Waters. University of Tennessee Studies in Geology, 3. Knoxville, Tennessee, pp. 144-157.

LINNÉ, C. 1767. Systema Naturae. 12th edition, v. 1, pt. 2. Laurentius Salvius, Holmiae, pp. 533-1327. [Not seen]

MACURDA, D.B., JR. and MEYER, D.L. 1975. The microstructure of the crinoid endoskeleton. University of Kansas Paleontological Contributions, Paper 74, $22 \mathrm{p}$.

- 1976. The morphology and life habits of the abyssal crinoid Bathycrinus aldrichianus Wyville Thomson and its paleontological implications. Journal of Paleontology, 50, pp. 647-667.

MACURDA, D.B., JR. and Roux, M. 1981. The skeletal morphology of the isocrinid crinoids Annacrinus wyvillethomsoni and Diplocrinus maclearanus. Contributions from the Museum of Paleontology, University of Michigan, 25, pp. 169-219.

MeYer, D.L. and AUSICH, W.I. 1983. Biotic interactions among Recent and among fossil crinoids. In Biotic Interactions in Recent and Fossil Benthic Communities. Edited by M.J.S. Tevesz and P.L. McCall. Plenum, New York, pp. 377-427.

Meyer, D.L., Messing, C.G., and Macurda, D.B., Jr. 1978. Zoogeography of tropical western Atlantic Crinoidea (Echinodermata). Bulletin of Marine Science, 28, pp. 412-441.

Miller, J.S. 1821. A Natural History of the Crinoidea or Lily-shaped Animals, with Observations on the Genera Asteria, Eurayle, Comalula and Marsupites. Bryan and Co., Bristol, 150 p.

MOORE, R.C., JefFords, R.M., and Miller, T.H. 1968. Morphological features of crinoid columns. University of Kansas, Paleontological Contributions, Echinodermata Article 8, $30 \mathrm{p}$.

Oı, T. 1990. Miocene Isocrinidae (stalked crinoids) from Japan and their biogeographic implication. Transactions and Proceedings of the Palaeontological Society of Japan, new series, no. 157, pp. $412-429$.

Pindell, J.L. and Barrett, S.F. 1990. Geological evolution of the Caribbean region: a plate-tectonic perspective. In The Geology of North America. Volume H. The Caribbean Region. Edited by G. 
Dengo and J.E. Case. Geological Society of America, Boulder, pp. 405-432.

Rasmussen, H.W. 1978. Articulata. In Treatise on Invertebrate Paleontology, Pt. T, Echinodermata 2(3), Crinoidea. Edited by R.C. Moore and C. Teichert. Geological Society of America and University of Kansas Press, Boulder and Lawrence, pp. T813-T928.

Robinson, E. 1969. Geological field guide to Neogene sections in Jamaica West Indies. Journal of the Geological Society of Jamaica, 10, pp. 1-24.

1971. Late Tertiary erosion surfaces and Pleistocene sea levels in Jamaica. In Transactions of the 5th Caribbean Geological Conference, St. Thomas, Virgin Islands, 1st-5th July, 1968. Edited by P.H. Mattson. Queens College Press, New York, pp. 213-221.

Roux, M. 1977. The stalk-joints of Recent Isocrinidae (Crinoidea). Bulletin of the British Museum (Natural History), Zoology, 32, pp. 45-64.

Sieverts-Doreck, H. 1952. In Invertebrate Fossils. Written by R.C. Moore, C.G. Lalicker, and A.G. Fischer. McGraw-Hill, New York, $766 \mathrm{p}$.
1953. In Traité de Paléontologie, Classe des Crïnoides, volume 3. Written by G. Ubaghs. Edited by J. Piveteau. Masson, Paris, pp. 658-773. [Not seen]

Simms, M.J. 1988. The phylogeny of the post-Palaeozoic crinoids. In Echinoderm Phylogeny and Evolutionary Biology. Ediled by C.R.C. Paul and A.B. Smith. Clarendon Press, Oxford, pp. 269-284.

Thomson, C.W. 1864. Sea lilies. The Intellectual Observer, 6, pp. 1-11.

1877. The voyage of the Challenger. The Atlantic, 2, $396 \mathrm{p}$. [Not seen]

Ubaghs, G. 1978. Skeletal morphology of fossil crinoids. In Treatise on Invertebrate Paleontology, Pt. T, Echinodermata 2(1), Crinoidea. Edited by R.C. Moore and C. Teichert. Geological Society of America and University of Kansas Press, Boulder and Lawrence, pp. T58-T216.

Webster, G.D. 1974. Crinoid pluricolumnal noditaxis patterns. Journal of Paleontology, 48, pp. 1283-1288.

Zittell, K.A., Von. 1879. Handbuch der Palăontologie. I. Protozoa, Coelenterata, Echinodermata und Molluscoidea. München and Leipzig, 765 p. 